\title{
Cisplatin Augments Antitumor T-Cell Responses Leading to a Potent Therapeutic Effect in Combination With PD-L1 Blockade
}

\author{
DAIKO WAKITA, TOSHIKI IWAI, SUGURU HARADA, MIHO SUZUKI, \\ KANAME YAMAMOTO and MASAMICHI SUGIMOTO \\ Product Research Department, Kamakura Research Laboratories, \\ Chugai Pharmaceutical Co., Ltd., Kanagawa, Japan
}

\begin{abstract}
Background: Immune checkpoint inhibitors have marked antitumor effect. However, monotherapy benefits only a limited population of patients, and further improvement of their effects is required. Here the therapeutic effect and immune response during anti-PD-L1 plus cisplatin combination therapy were investigated in a mouse model. Materials and Methods: E.G7-OVA, expressing ovalbumin (OVA) gene as a model tumor antigen, was subcutaneously inoculated into syngeneic mice and treated with anti-PD-LI with/without cisplatin. The tumor growth and activation status of immune cells were evaluated. Results: The anti-PDL1 plus cisplatin combination resulted in a potent antitumor effect leading to tumor shrinkage compared to anti-PD-L1 or cisplatin alone, even though each alone, significantly inhibited tumor growth compared to the control group. During treatment, all groups, including that treated with cisplatin alone, had increased $C D 8^{+} T$-cell infiltration into tumor tissues compared with the control group, and the therapeutic effect was diminished by $\mathrm{CD}^{+}$cell depletion. Aside from its direct cytotoxic effect, cisplatin alone increased chemokine levels and expression of immune checkpoint molecules on $C D 8^{+} T$-cells in the tumor site. The combination effectively activated OVA-specific CD ${ }^{+} T$-cells. Furthermore, anti-PD-L1 alone and in combination with cisplatin, but not cisplatin alone, induced interferon-gammaproducing $\mathrm{CD}^{+}$T-cells. Conclusion: These findings provide
\end{abstract}

This article is freely accessible online.

Correspondence to: Masamichi Sugimoto, Product Research Department, Kamakura Research Laboratories, Chugai Pharmaceutical Co., Ltd., 200 Kajiwara, Kamakura, Kanagawa 2478530, Japan. Tel: +81 467457692, Fax: +81 467457643, e-mail: sugimotomsm@chugai-pharm.co.jp

Key Words: Cisplatin, combination therapy, PD-L1, cytotoxic T-cell, Th1. a rationale for anti-PD-L1 plus cisplatin becoming a promising combination therapy for patients with cancer.

Immune checkpoint inhibitors targeting programed deathligand 1 (PD-L1), programed cell death-1 (PD-1), or cytotoxic T-lymphocyte antigen 4 molecules show substantial antitumor effects in patients with several types of cancers (1-4). A unique feature of cancer immunotherapy is that immune checkpoint inhibitors can induce durable clinical responses, unlike chemotherapies and molecularly-targeted therapies $(5,6)$. However, only a minor population of patients respond to immune checkpoint inhibitor therapy administered as a single agent (6-8), and there is evidence that the clinical outcomes might be associated with PD-L1 expression in the tumor microenvironment and with tumor-infiltrating T-cell responses (9). In addition, it has been reported that patients with a higher mutation burden - and, therefore, a larger variety of neoantigens - appear to derive greater clinical benefit from immune checkpoint inhibitors (10-12), and viral oncolysis, which induces tumor destruction and subsequent release of antigens, was shown to activate specific T-cell responses against a broad range of neoantigens in a mouse model (13). Thus, there is a growing interest in therapies that utilize immune checkpoint inhibitors in combination with agents that elicit tumor cell death, including chemotherapies and molecularly-targeted therapies $(10,14)$.

Chemotherapy is a gold-standard strategy for the treatment of cancer, and the primary role of chemotherapeutic agents is the direct killing of cancer cells. However, it is reported that some chemotherapies also increase antitumor immune response by reducing immune-suppressive cells, including myeloid-derived suppressor cells and regulatory T-cells, or upregulating major histocompatibility complex class I (MHC-I) on tumor cells (15-17). In addition, there is evidence that under certain conditions, chemotherapeutic agents also induce immunogenic cell death (ICD), which induces production of immune-activating molecules and uptake of tumor cells by dendritic cells, resulting in the activation of acquired immunity 
against tumor cells (18). On the other hand, chemotherapy also induces PD-L1 expression on tumor cells or immune cells, resulting in resistance to the immune therapy (19-21).

These results led us to investigate the possibility of combination therapy with immune checkpoint inhibitors plus anticancer drugs. Cisplatin has been used in a wide range of tumor types as a standard-of-care therapy. However, there are still conflicting reports on the impact of cisplatin on the immune system, and the therapeutic effect and underlying mechanisms of combination therapy of immune checkpoint inhibitors with cisplatin is still largely unknown.

\section{Materials and Methods}

Mice. Female, 7-week-old C57BL/6 mice were obtained from Charles River Laboratories Japan, Inc. (Kanagawa, Japan). All animal experiments were performed in accordance with the Guidelines for the Care and Use of Laboratory Animals at Chugai Pharmaceutical Co. Ltd., and all animal procedures were reviewed and approved by the Institutional Animal Care and Use Committee at Chugai Pharmaceutical Co., Ltd. (approval number: 16-076).

Cell lines and culture conditions. Cell lines E.G7-OVA and EL4 were purchased from the American Type Culture Collection (Manassas, VA, USA). E.G7-OVA and EL4 were maintained in RPMI-1640 (SigmaAldrich, St. Louis, MO, USA) supplemented with $10 \%$ (v/v) fetal bovine serum (Bovogen Biologicals, Melbourne, Australia), $2.5 \mathrm{~g} / \mathrm{I}$ D-glucose (Sigma-Aldrich), $1 \mathrm{mM}$ sodium pyruvate (Thermo Fisher Scientific Inc., Waltham, MA, USA), 10 mM HEPES (SigmaAldrich), and $50 \mu \mathrm{M}$ 2-mercaptoethanol (Wako Pure Chemical Industries, Osaka, Japan) at $37^{\circ} \mathrm{C}$ under $5 \% \mathrm{CO}_{2}$. For E.G7-OVA culture

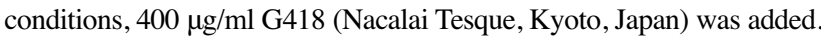

Tumor-bearing mouse model and in vivo treatment. E.G7-OVA cells $\left(1 \times 10^{6}\right.$ cells $)$ were subcutaneously inoculated into syngeneic C57BL/6 mice, and tumor growth was monitored. Tumor size was measured with calipers and the tumor volume (TV) was calculated by the following formula: TV $\left(\mathrm{mm}^{3}\right)=\left\{\right.$ length $\left.(\mathrm{mm}) \times[\text { width }(\mathrm{mm})]^{2}\right\} / 2$. When the tumor mass became palpable, mice were divided into control and treatment groups and drug administration was started (day 1). Anti-mouse PD-L1 monoclonal antibody (clone 10F.9G2; BioLegend Inc., San Diego, CA, USA) or Rat IgG (MP Biomedicals, Santa Ana, CA, USA) was intraperitoneally administered at $10 \mathrm{mg} / \mathrm{kg}$, three times a week for 2 weeks in the therapeutic experiments. In the analytical experiments, antiPD-L1 was administered on day 1 and day 3. Cisplatin (Nippon Kayaku Co., Ltd., Tokyo, Japan) or saline was intraperitoneally administered at $1 \mathrm{mg} / \mathrm{kg}$ on day 1 . Complete tumor regression (CR) was defined as a tumor volume below the limit of detection $\left(\leq 10 \mathrm{~mm}^{3}\right)$.

For $\mathrm{CD}^{+}$cell-depletion in the experiments evaluating antitumor effect, mice bearing E.G7-OVA were injected with anti-mouse CD8 monoclonal antibody (clone 2.43; Bio X Cell, West Lebanon, NH, USA) at $200 \mu \mathrm{g} /$ injection on day -1 and at $100 \mu \mathrm{g} /$ injection thereafter twice a week.

Cell preparation. Tumor tissues were dissected from E.G7-OVAbearing mice on day 7 . Tumors were minced and digested with mouse tumor dissociation kit (Miltenyi Biotec, Bergisch Gladbach, Germany) according to the manufacturer's protocol.
Axillary and inguinal lymph nodes ipsilateral and contralateral with respect to the tumor were collected as tumor-draining lymph nodes (TDLNs) and non-TDLNs, respectively. Minced lymph nodes were digested with $1 \mathrm{mg} / \mathrm{ml}$ collagenase D (Roche, Basel, Switzerland) at $37^{\circ} \mathrm{C}$ for $15 \mathrm{~min}$ while shaken under rotation. Single-cell suspensions were prepared by passing through a cell strainer.

Flow cytometry. Single-cell suspensions were incubated with antimouse CD16/CD32 (Tonbo Biosciences, San Diego, CA, USA ) and fixable viability dyes (FVD) eFluor 506 or eFluor 780 (eBioscience, San Diego, CA, USA) at room temperature for 5 minutes, and then stained with the following conjugated antibodies for cell surface molecules at $4^{\circ} \mathrm{C}$ for 15 minutes: Fluorescein isothiocyanate (FITC)CD8 (MBL International, Woburn, MA, USA), Alexa Fluor 700CD3e, allophycocyanin (APC)- CyChrome (Cy)7-CD45, brilliant violet (BV)421-PD-1, BV711-CD11c (BioLegend), peridininchlorophyll-protein complex (PerCP)-Cy5.5-CD45, BV650-CD4, phycoerythrin (PE)-CF594-CD80, BV510-CD11b, alexa fluor 647major histocompatibility complex class II (MHC-II), PE-CF594F4/80, PE-PD-L1 (BD Biosciences, San Jose, CA, USA).

For detection of ovalbumin (OVA)-specific CD8+ T-cells, cells were incubated with PE-major histocompatibility complex (MHC)-OVAtetramer (MBL International) at room temperature for 30 minutes.

For detection of interferon-gamma (IFN $\gamma$ )-producing cells, cells were stimulated with plate-bound anti-mouse CD3 and anti-mouse CD28 monoclonal antibodies (BD Biosciences) in the presence of brefeldin A (Sigma-Aldrich) at $37^{\circ} \mathrm{C}$ for 4 hours and then stained with antibodies for cell surface molecules as described above.

For staining of intracellular molecules, cells were fixed and permeabilized with a forkhead box P3 (FOXP3)/Transcription Factor Staining Kit (eBioscience) according to the manufacture's protocol and then stained with the following conjugated antibodies at $4^{\circ} \mathrm{C}$ for 30 minutes: PerCP-Cy5.5-FOXP3 (eBioscience), Alexa Fluor 647granzyme B (GZMB), BV786-Ki67 (BD Biosciences), APC-IFN $\gamma$ (Tonbo Biosciences).

Data were acquired with an LSRFortessa X-20 cell analyzer (BD Biosciences) and analyzed using FlowJo software (Tree Star, Ashland, OR, USA).

Enzyme-linked immunosorbent assay (ELISA). Tumor tissues were collected on day 3 from the control and cisplatin-treated group and homogenized. After centrifugation $\left(20,400 \mathrm{~g}\right.$ for $10 \mathrm{~min}$ at $\left.4^{\circ} \mathrm{C}\right)$, supernatants were harvested and protein concentrations were measured with a Direct Detect spectrometer (Merck Millipore, Burlington, MA, USA). Levels of C-X-C motif chemokine ligand 9 (CXCL9) and CXCL10 were determined by using a Quantikine ELISA kit (R\&D Systems, Minneapolis, MN, USA) and a Mouse IP10 ELISA kit (Thermo Fisher Scientific Inc.), respectively, following each manufacturer's protocol.

Cytotoxicity. $\mathrm{CD}^{+}{ }^{+}$T-cells were isolated from TDLN cells by a CD8 ${ }^{+}$ cell enrichment kit (Miltenyi Biotec). E.G7-OVA and EL4 were used as target cells. These tumor cells were labeled with carboxyfluorescein diacetate succinimidyl ester (CFSE; Thermo Fisher Scientific Inc.) and co-cultured with isolated $\mathrm{CD} 8^{+} \mathrm{T}$-cells at effector/target $(\mathrm{E} / \mathrm{T})$ ratio of 10,20 and 40 at $37^{\circ} \mathrm{C}$ for $16 \mathrm{~h}$ in a 96 -well V-bottom plate. Cells were stained with FVD eFluor 780 (eBioscience) and the ratio of dead FVD eFluor 780+ cells among the $\mathrm{CFSE}^{+}$tumor cells was detected with an LSRFortessa X-20 cell analyzer. The data were analyzed by FlowJo software and the cytotoxic activity was calculated by following 

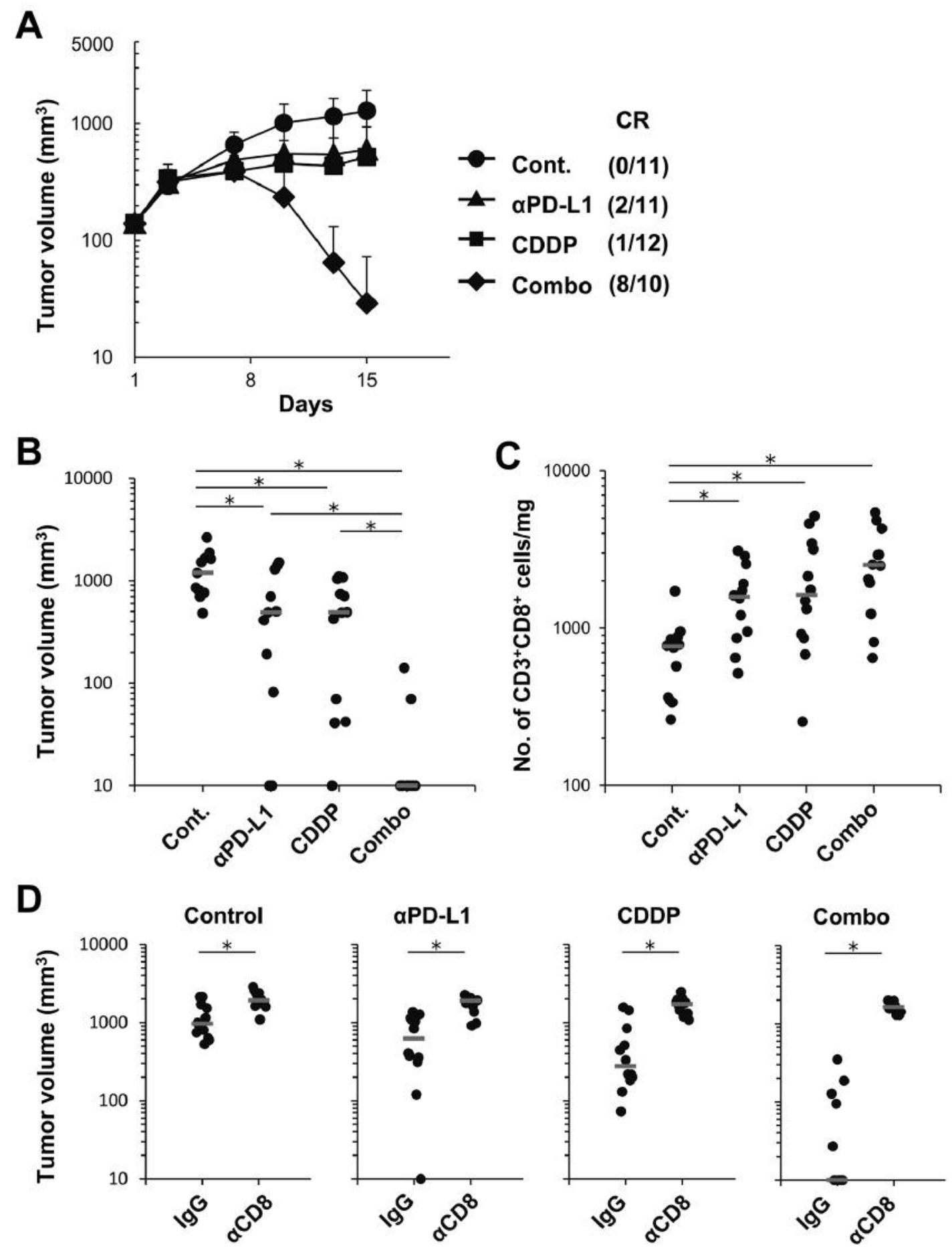

Figure 1. Combination therapy with anti-programed death-ligand 1 (PD-L1) plus cisplatin promoted antitumor effect in a syngeneic mouse tumor model. A: C57BL/6 mice were subcutaneously inoculated with E.G7-OVA cells and treated with $10 \mathrm{mg} / \mathrm{kg}$ anti-PD-L1 antibodies ( $\alpha P D-L 1)$ three times a week for 2 weeks, $1 \mathrm{mg} / \mathrm{kg}$ cisplatin $(C D D P)$ on day 1 , or a combination of both (combo). The tumor volume (mean $+S D)$ is shown. The number of mice with complete tumor regression (CR) out of the total number of mice per group is shown to the right of the graph. B: Dots represent the tumor volume of each mouse on day 15 and bars show the median of 10-12 mice per group. C: Tumor-infiltrating $C D 3^{+} C D 8^{+}$cells were detected by flow cytometry on day 7 and the number of $C D 3^{+} C D 8^{+} T$-cells per mg of tumor tissues was calculated. D: E.G7-OVA-bearing mice were injected with control IgG or anti-CD8 antibodies $(\alpha C D 8)$. One day after the first injection, the indicated treatment were initiated as described above (A). Dots represent the tumor volume of each mouse on day 13 and bars show the median of 12 mice per group. *Significantly different at p<0.05, significant differences were determined by Wilcoxon test alone $(D)$ and with Holm-Bonferroni method $(B, C)$. 

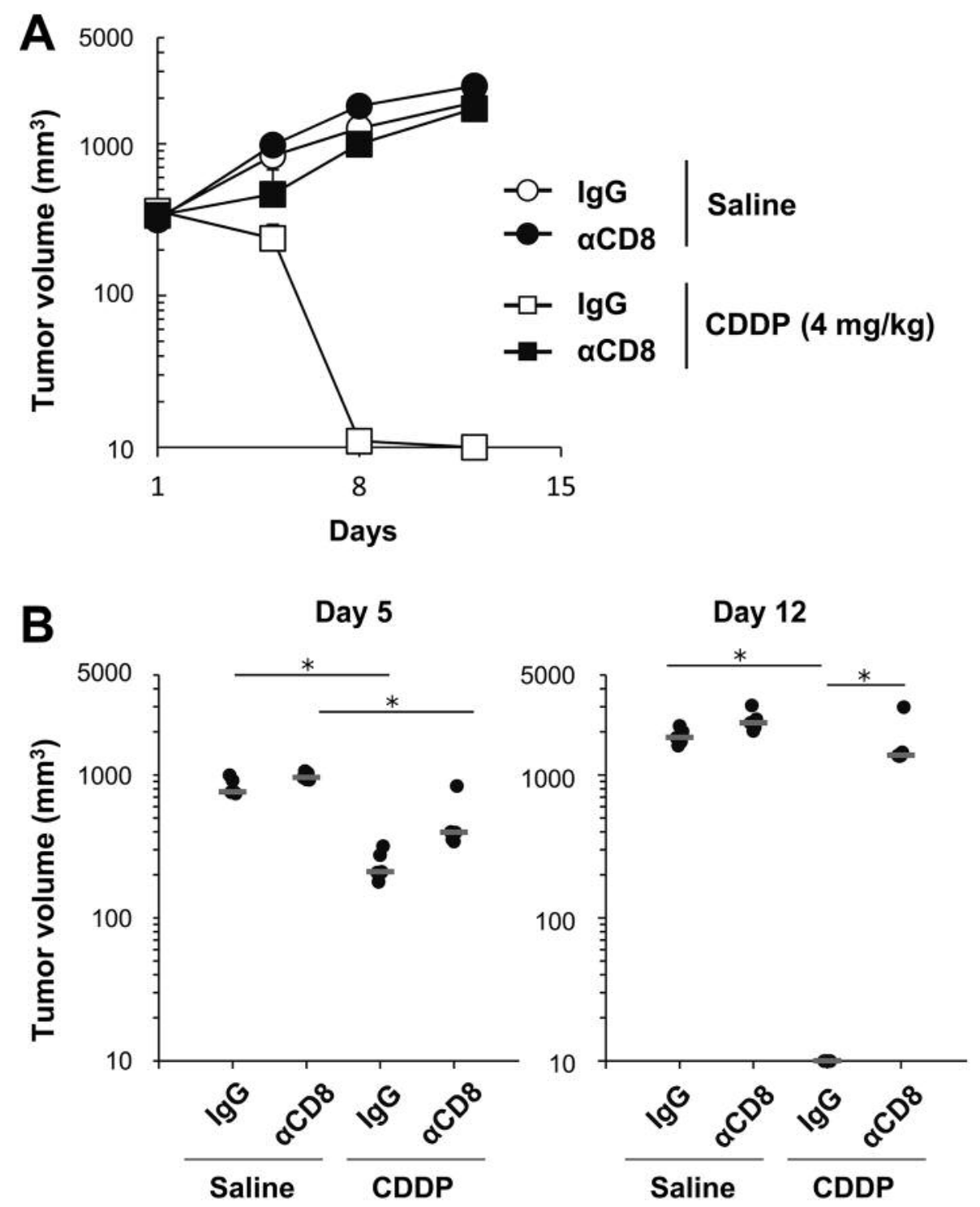

Figure 2. $C D 8^{+} T$-cells played a crucial role in the antitumor effect of cisplatin even at a higher dose. C57BL/6 mice were subcutaneously inoculated with E.G7-OVA cells and treated with $4 \mathrm{mg} / \mathrm{kg}$ cisplatin (CDDP) or saline (Cont.). For cell depletion, anti-CD8 antibodies ( $\alpha C D 8)$ or control IgG were injected. A: Tumor volumes (mean+SD) are shown. B: Dots represent the tumor volume of each mouse on day 5 or 12 and bars show the median of five mice per group. *Significantly different at $p<0.05$, Wilcoxon test.

formula: $\%$ cytotoxicity $=[(\%$ targeted dead cells $-\%$ spontaneous dead cells $) /(100-\%$ spontaneous dead cells $)] \times 100$.

Statistics. To evaluate the statistical significance, data for tumor growth and flow cytometry experiments were analyzed with the Wilcoxon test and those for cytotoxicity analysis with Student's $t$-test. For comparison of two groups, differences with $p<0.05$ were considered to indicate a significant difference. In the analysis of combination effects, statistical analysis was performed between the control group and the other groups, and between the combination group and the groups treated with anti-PD-L1 or cisplatin alone. The significant $p$-values were adjusted for multiple comparisons by the Holm-Bonferroni method. All statistical analyses were performed in JMP software (SAS Institute, Cary, NC, USA).

\section{Results}

Anti-PD-L1 plus cisplatin combination therapy promoted antitumor activity in a syngeneic mouse tumor model. Initially, in order to examine the antitumor effects of combination therapy using anti-PD-L1 plus cisplatin in vivo, 
A

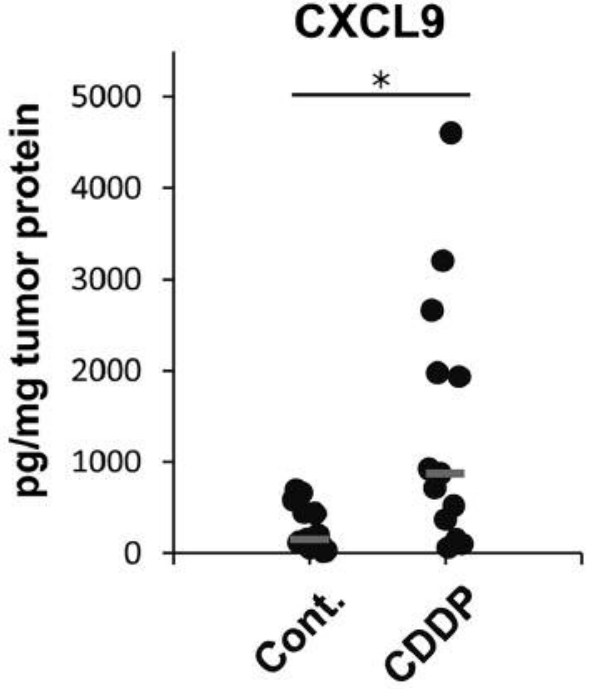

B

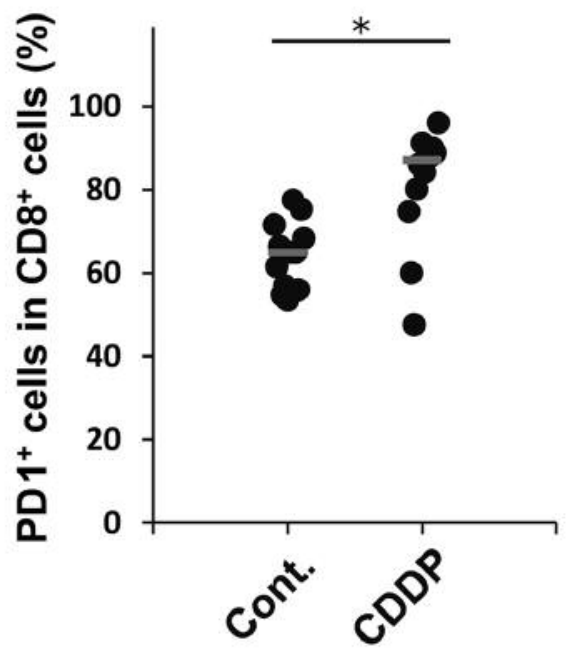

CXCL10
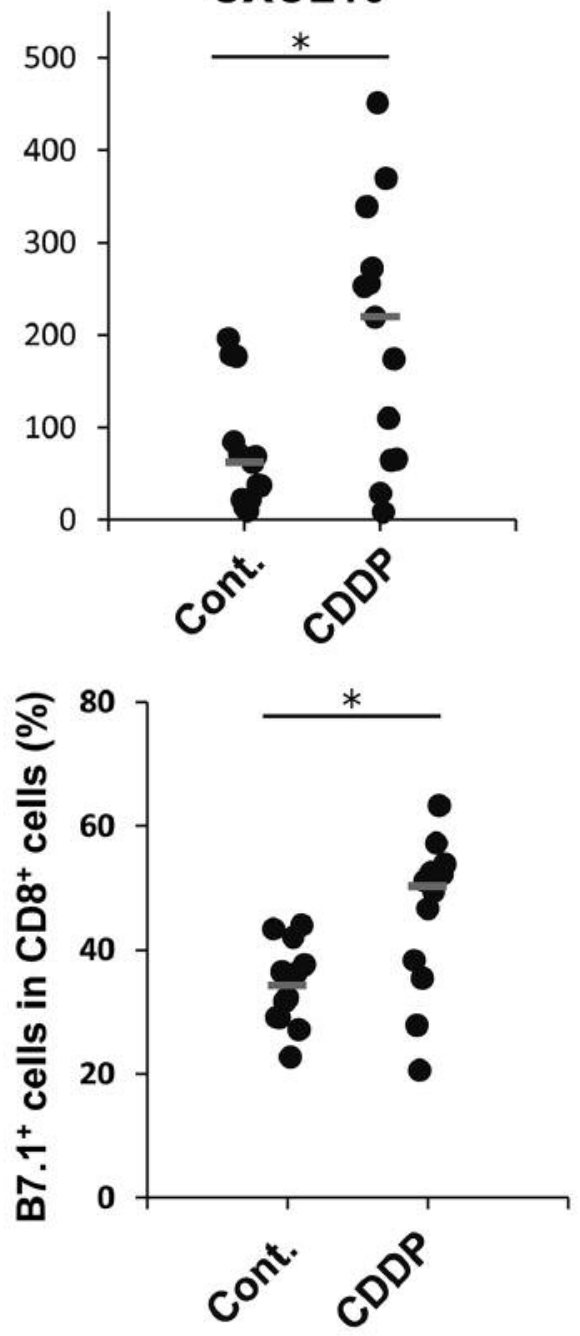

C

\section{Control}

CDDP

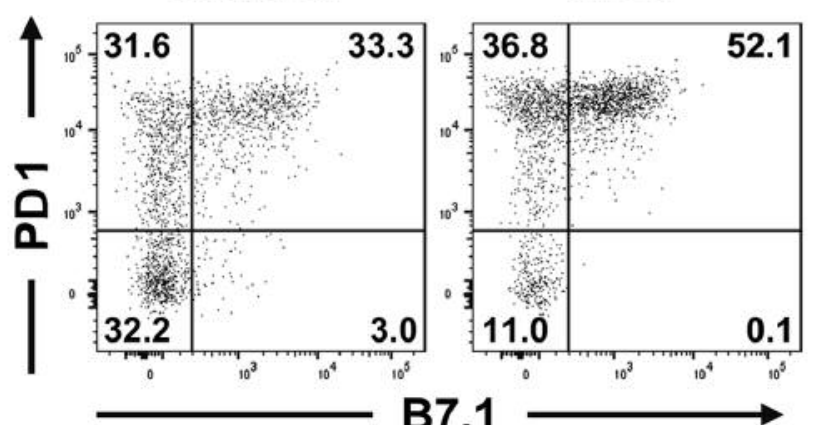

Figure 3. Cisplatin (CDDP) increased chemokine levels and expression of immune checkpoint molecules on CD8+ T-cells. E.G7-OVA-bearing mice were treated with $1 \mathrm{mg} / \mathrm{kg}$ cisplatin $(C D D P)$ or saline (Cont.) on day 1. A: On day 3, tumor tissues were collected and the levels of $C$-X-C motif chemokine ligand 9 (CXCL9) and CXCL10 in the tumor homogenates were determined by enzyme-linked immunosorbent assay. Dots represent the value for each mouse and bars show the median of 13 mice per group. B: On day 7, the percentages of programed cell death-1 (PD1)+ and B7.1 $1^{+}$ cells among tumor-infiltrating CD8+ T-cells were determined by flow cytometry. Dots represent the value for each mouse and bars show the median of 12 mice per group. C: Representative flow cytometric profiles of CD8+ T-cells are shown. ${ }^{*}$ Significantly different at $p<0.05$, Wilcoxon test. 

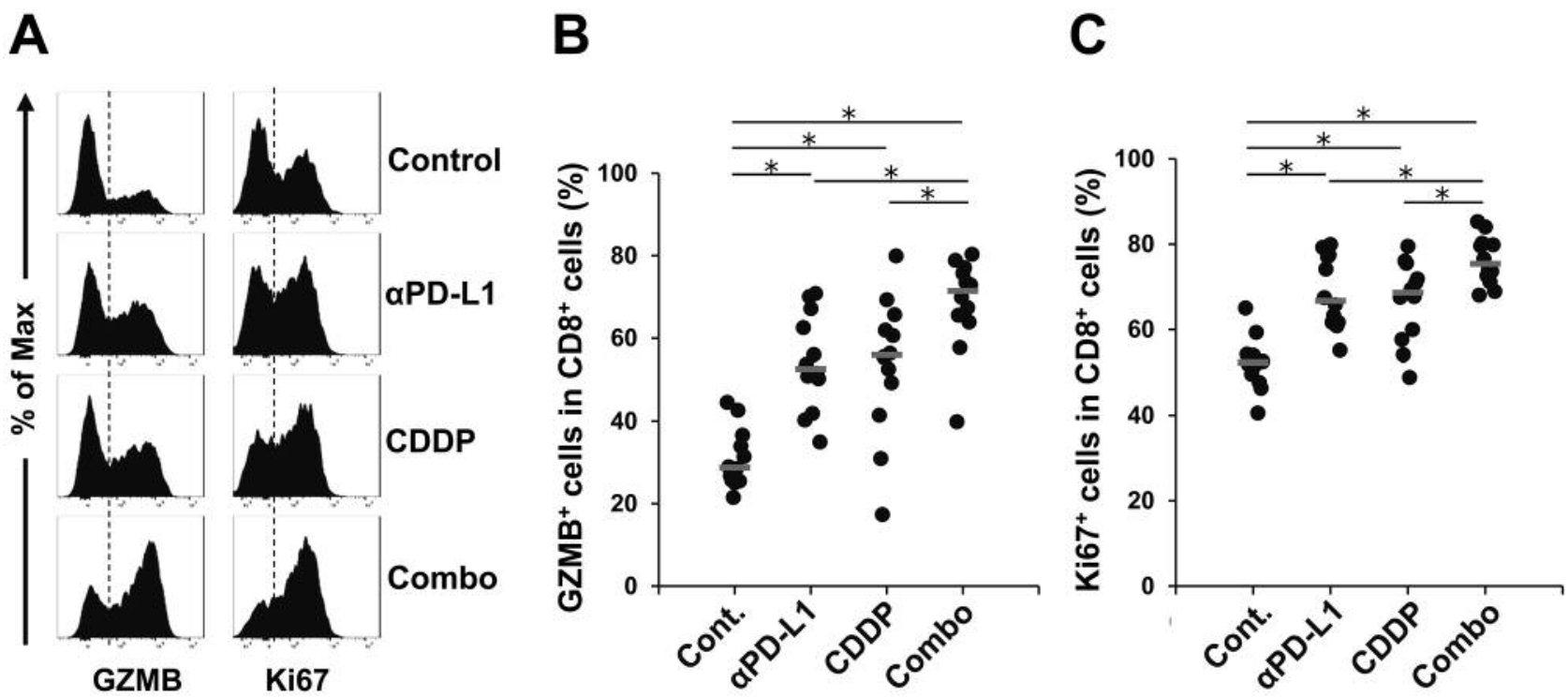

Figure 4. Combination therapy with anti-programed death-ligand 1 (PD-L1) plus cisplatin (CDDP) increased effector CD8 $8^{+}$T-cells in tumor tissues. E.G7-OVA-bearing mice were treated with $10 \mathrm{mg} / \mathrm{kg}$ anti-PD-L1 ( $\alpha P D-L 1)$ on day 1 and day 3, $1 \mathrm{mg} / \mathrm{kg}$ cisplatin (CDDP) on day 1, or a combination of both (combo). On day 7, granzyme B $(G Z M B)^{+}$and Ki67+ cells among the tumor-infiltrating $C D 8^{+} T$-cells were determined by flow cytometry. A: Representative histograms of GZMB and Ki67 gated on CD8+ T-cells. Quantitative analysis of GZMB ${ }^{+}(C)$ and Ki67+ $(D)$ cells Dots represent the values for each mouse and bars show the median of 12 mice per group. *Significantly different at $p<0.05$, Wilcoxon test with Holm-Bonferroni method.

we utilized E.G7-OVA tumor-bearing mouse model. Treatment with anti-PD-L1 or cisplatin alone significantly inhibited tumor growth compared with control treatment (Figure 1A and B). Notably, the combination therapy led to antitumor effects even greater than those resulting from treatment with anti-PD-L1 or cisplatin alone. The combination therapy induced shrinkage of tumor tissues and $80 \%$ of mice showed complete tumor regression on Day 15 (Figure 1A).

Evaluation of $\mathrm{CD}^{+} \mathrm{T}$-cell migration into tumor tissues during the treatment revealed that both treatment with antiPD-L1 alone and in combination therapy increased CD8 ${ }^{+} \mathrm{T}-$ cell infiltration compared with the control on day 7 (Figure 1C), and there were also more $\mathrm{CD} 8^{+} \mathrm{T}$-cells in tumor tissues of cisplatin-treated mice than in control mice (Figure 1C). To investigate whether the increase in tumor-infiltrating $\mathrm{CD}^{+}{ }^{+} \mathrm{T}$-cells led to the antitumor effect, we evaluated tumor growth under $\mathrm{CD} 8^{+} \mathrm{T}$-cell depletion. The therapeutic effects of anti-PD-L1 treatment were completely abrogated by the depletion of $\mathrm{CD}^{+}$cells (Figure 1D). Furthermore, cisplatin alone and anti-PD-L1 plus cisplatin combination therapy also both failed to inhibit tumor growth in the absence of $\mathrm{CD} 8^{+}$ cells in vivo (Figure 1D). To exclude the possibility that this loss of antitumor effect was due to the low dose of cisplatin $(1 \mathrm{mg} / \mathrm{kg})$, we also confirmed that administration of cisplatin at $4 \mathrm{mg} / \mathrm{kg}$ led to both a direct $\mathrm{CD} 8^{+}$T-cell-independent antitumor effect in the early phase and $\mathrm{CD}^{+}$T-cell- dependent eradication of tumors in the late phase (Figure 2). These findings indicate that $\mathrm{CD} 8^{+} \mathrm{T}$-cells play a pivotal role in the antitumor effects of cisplatin as well as of anti-PD-L1 in this model.

Cisplatin increased chemokine levels and expression of immune checkpoint molecules on $C D 8^{+} T$-cells at tumor sites. Because chemokines play a crucial role in the recruitment of effector $\mathrm{CD} 8^{+} \mathrm{T}$-cells into tumor tissues in several models, here we evaluated the intratumor levels of CXCL9 and CXCL10, which are chemoattractants for $\mathrm{CD}^{+} \mathrm{T}$-cells (22). In comparison with the control group, cisplatin treatment significantly elevated the levels of these chemoattractants in tumor tissues, indicating the possible function of cisplatin in recruitment of $\mathrm{CD} 8^{+} \mathrm{T}$-cells via increase of chemokine levels (Figure 3A). Importantly, we found that higher percentages of tumor-infiltrating $\mathrm{CD} 8^{+}$T-cells expressed PD-1 and B7.1, both of which bind to PD-L1, in the cisplatin group than in the control group (Figure 3B). Furthermore, most of the B7. ${ }^{+} \mathrm{CD}^{+}$T-cells co-expressed PD-1 (Figure 3C). Moreover, we observed the expression of PD-L1 on E.G7OVA tumor cells and on tumor-infiltrating dendritic cells and macrophages (data not shown). These data suggest the potential rationale that an antibody against PD-L1 would engage blockade of both the PD-L1-PD1 and PD-L1-B7.1 pathways which were promoted by cisplatin treatment in the combination setting. 
A

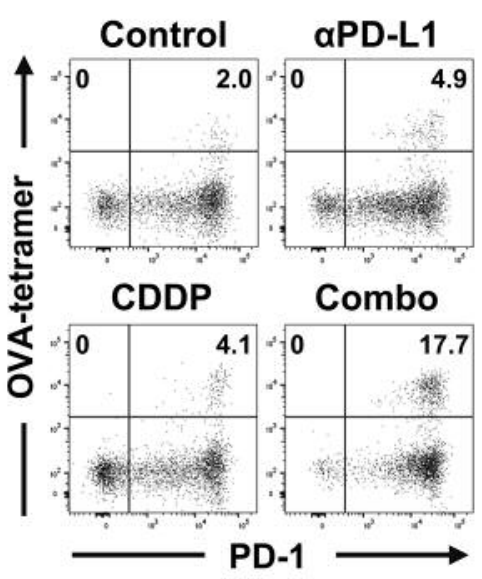

B

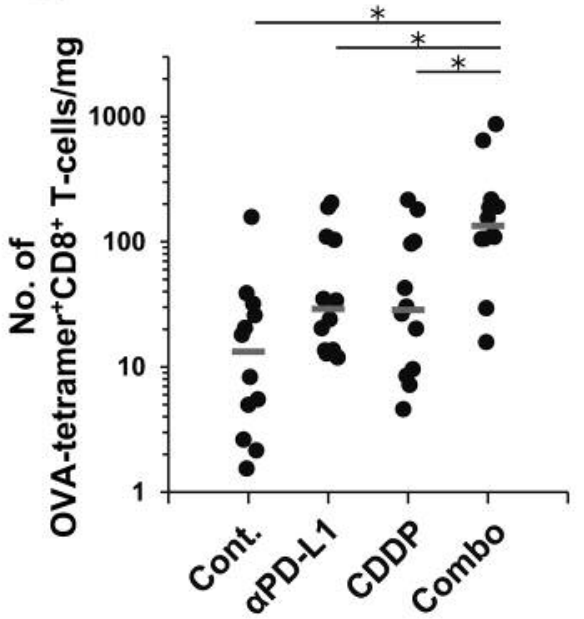

C

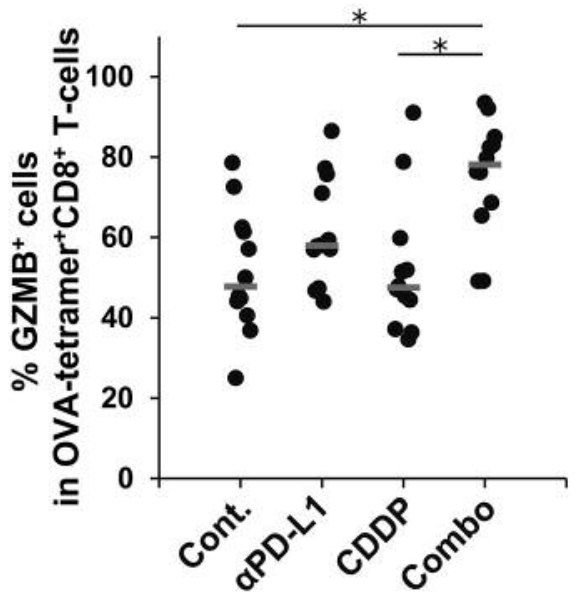

Figure 5. Combination therapy with anti-programed death-ligand 1 (PD-L1) and cisplatin (CDDP) activated tumor-specific cytotoxic T lymphocytes in tumor tissues. E.G7-OVA-bearing mice were treated with $10 \mathrm{mg} / \mathrm{kg}$ anti-PD-L1 ( $\alpha P D-L 1)$ on day 1 and day $3,1 \mathrm{mg} / \mathrm{kg}$ cisplatin (CDDP) on day 1, or a combination of both (combo). On day 7, tumor tissues were collected and used for flow cytometry. A: Representative flow cytometric profiles of $C D 8^{+} T$-cells. B: The percentages of OVA-tetramer ${ }^{+}$cells among CD8+ T-cells were determined by flow cytometry and the number of OVAtetramer ${ }^{+} C D 8^{+} T$-cells per $m g$ of tumor tissue was calculated. $C$ : The percentages of granzyme $B(G Z M B)^{+}$cells among $O V A-t e t r a m e r+C D 8^{+}$ $T$-cells were determined by flow cytometry. Dots represent the value for each mouse and bars show the median of 12 mice per group. *Significantly different at $p<0.05$, Wilcoxon test with Holm-Bonferroni method.

Anti-PD-L1 plus cisplatin combination therapy augmented effector $C D 8^{+} T$-cell responses. Next, to evaluate the impact of anti-PD-L1 plus cisplatin combination therapy on effector function of $\mathrm{CD}^{+} \mathrm{T}$-cells, the activation status of tumorinfiltrating $\mathrm{CD}^{+}$T-cells on day 7 was evaluated. In accordance with the antitumor effect (Figure 1A), treatment with not only anti-PD-L1, but also cisplatin alone increased the frequencies of $\mathrm{GZMB}^{+}$and $\mathrm{Ki} 7^{+}$cells among the tumorinfiltrating $\mathrm{CD}^{+} \mathrm{T}$-cells, compared with the control group (Figure 4). Notably, the populations of these effector $\mathrm{CD}^{+}$ T-cells were further increased by the combination therapy, suggesting that combination therapy would result in enhanced therapeutic effects through the augmentation of $\mathrm{CD}^{+} \mathrm{T}$-cell function in tumor tissues.

Combination therapy increased tumor-specific $C D 8^{+}$T-cells with functional phenotypes in tumor tissues. E.G7-OVA expresses OVA as an artificial model antigen, which allows us to investigate tumor-specific T-cell responses during treatment Treatment with anti-PD-L1 or cisplatin alone slightly increased the median number of OVA-tetramer ${ }^{+} \mathrm{CD} 8^{+} \mathrm{T}$-cells compared with the control, but the changes were not statistically significant; in contrast, combination therapy markedly increased OVA-tetramer ${ }^{+}$cells in tumor tissues compared with the other treatment groups (Figure 5A and B). Moreover, multiple staining analysis revealed that tumorinfiltrating OVA-tetramer ${ }^{+} \mathrm{CD} 8^{+}$T-cells expressed PD1
(Figure 5A). We found that OVA-specific $\mathrm{CD}^{+} \mathrm{T}$-cells in tumor tissues from mice treated with the combination therapy included higher frequencies of $\mathrm{GZMB}^{+}$cells than did OVAspecific $\mathrm{CD}^{+} \mathrm{T}$-cells from the control or cisplatin-treated groups (Figure 5C). The median percentage of $\mathrm{GZMB}^{+}$cells in the combination group was higher than that in the anti-PDL1 group but the difference was not statistically significant in this case. These results strongly suggest that tumor-specific $\mathrm{CD}^{+}$T-cells are promising targets of anti-PD-L1 treatment and that the elevated infiltration of functional tumor-specific CTLs would be a cause of the curative effects of combination therapy seen in this model.

Tumor-specific $C D 8^{+}$T-cells were activated in TDLNs during combination therapy. To further investigate the effects of these treatments on tumor-specific $\mathrm{CD}^{+} \mathrm{T}$-cells, we analyzed the OVA-tetramer ${ }^{+}$cells among cells of TDLNs and nonTDLNs. The number of OVA-specific T-cells among TDLN cells was significantly higher in the combination group than in the control group (Figure 6A). Similarly to the results observed in tumor tissues, we also found that anti-PD-L1 or cisplatin treatment tended to slightly increase the number of OVA-tetramer ${ }^{+} \mathrm{CD}^{+}{ }^{+} \mathrm{T}$-cells among the TDLN cells (Figure 6A). The induction of OVA-specific CTLs by combination therapy was observed only in TDLNs and not in non-TDLNs (Figure 6A), suggesting the importance of TDLNs in activation of tumor-specific T-cells. 

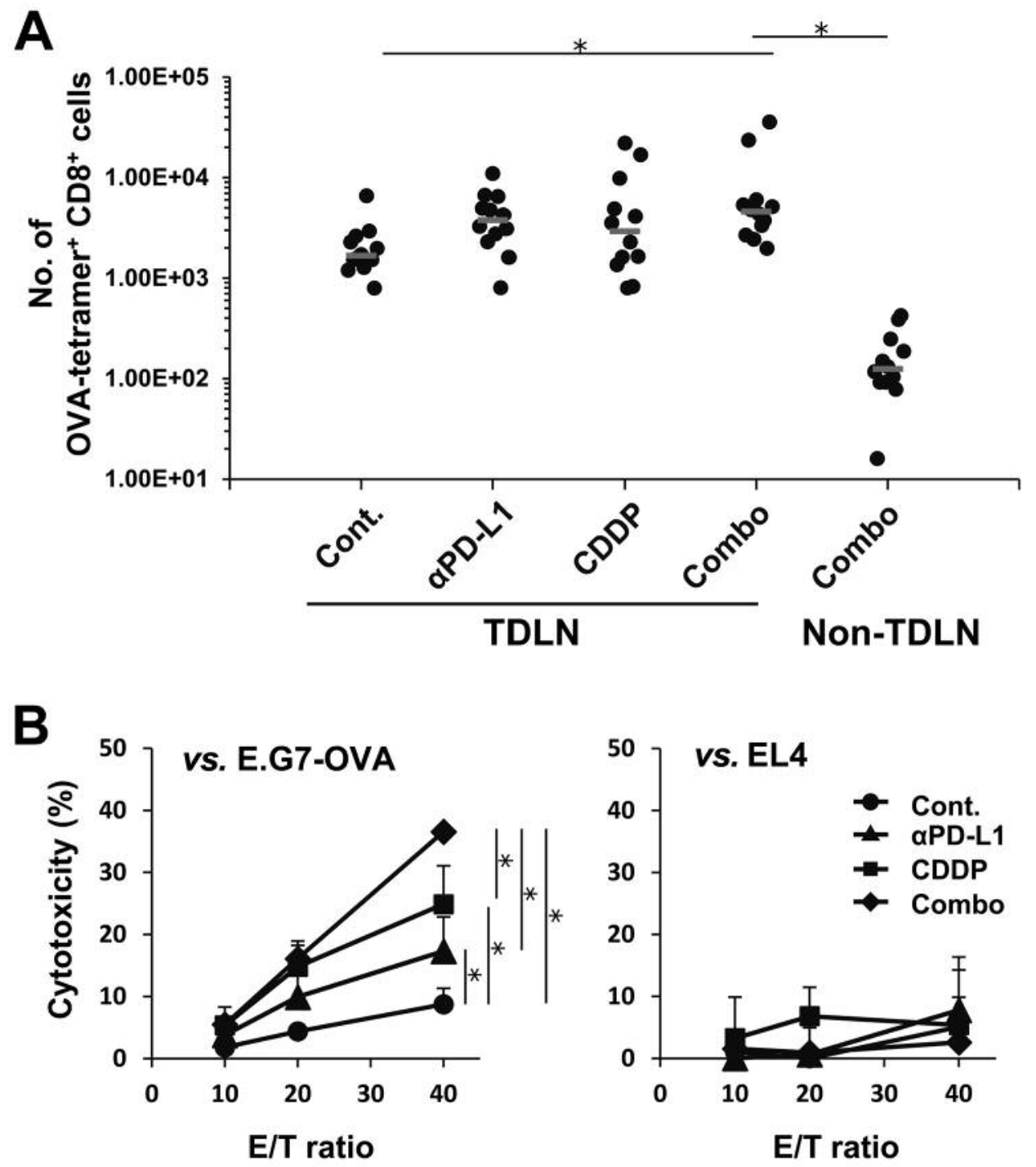

Figure 6. Tumor-specific cytotoxic T lymphocytes were activated in tumor-draining lymph nodes (TDLNs) during combination therapy. E.G7-OVAbearing mice were treated with $10 \mathrm{mg} / \mathrm{kg}$ anti-PD-L1 ( $\alpha P D-L 1)$ on day 1 and day $3,1 \mathrm{mg} / \mathrm{kg}$ cisplatin $(C D D P)$ on day 1 , or a combination of both (combo). On day 7, cells from TDLNs and non-TDLNs were collected. A: The percentages of OVA-tetramer ${ }^{+}$cells among CD8 ${ }^{+} T_{\text {-cells }}$ were determined by flow cytometry and the total number of $\mathrm{OVA}$-tetramer ${ }^{+} \mathrm{CD} 8^{+} \mathrm{T}$-cells were calculated. Dots represent the value for each mouse and bars show the median of 12 mice per group. B: CD8 ${ }^{+}$T-cells were isolated from pooled TDLN cells and cytotoxic activity against E.G7-OVA or EL4 was measured. Data show means \pm SD of triplicates. E/T: Effector/target ratio. *Significantly different at p<0.05, Wilcoxon test (A) or Student's t-test (B) with Holm-Bonferroni method.

To investigate the antitumor function, $\mathrm{CD} 8^{+} \mathrm{T}$-cells were isolated from TDLN cells and their OVA-specific cytotoxic activity was evaluated. $\mathrm{CD} 8^{+} \mathrm{T}$-cells from the combination therapy group showed significantly higher cytolysis activity against E.G7-OVA cells but not against EL4 cells as compared with $\mathrm{CD} 8^{+}$T-cells from each group treated with anti-PD-L1 or cisplatin alone (Figure 6B). In addition, in this analysis, anti-PD-L1 and cisplatin treatment each increased OVAspecific cytotoxic function significantly more than did the control treatment (Figure 6B).
Administration of anti-PD-LI but not cisplatin increased IFN $\gamma$ producing $\mathrm{CD}^{+} \mathrm{T}$-cells in tumor tissues. In addition to the role of $\mathrm{CD}^{+} \mathrm{T}$-cells, mounting evidence points to the critical role of $\mathrm{CD}^{+}{ }^{+} \mathrm{T}$-cells, especially IFN $\gamma$-producing T-helper type 1 (Th1) cells, in antitumor immune responses (23-25). Accordingly, we investigated the effects of these treatments on $\mathrm{CD}^{+}{ }^{+} \mathrm{T}$-cell migration and function. Unexpectedly, total numbers of $\mathrm{CD} 4^{+} \mathrm{T}$-cells and $\mathrm{FOXP} 3^{+}$regulatory T-cells in tumor tissues were not influenced by any of the treatments in the current study (Figure 7A and B). In addition, we observed 
A

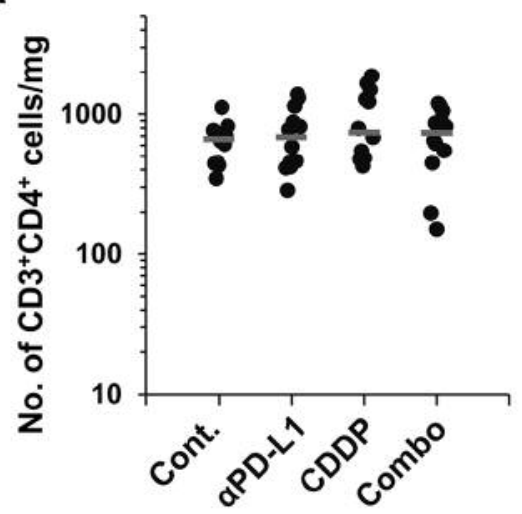

C

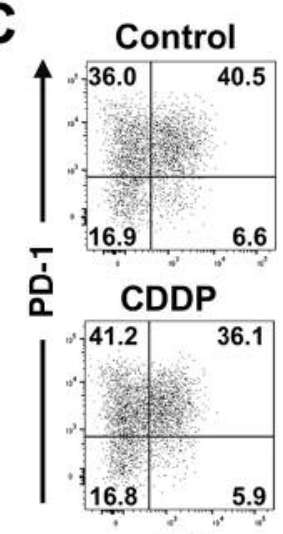

- B7.1
B

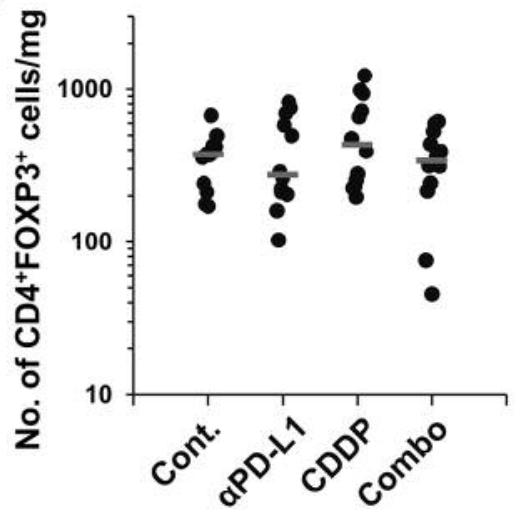

E

$\mathbf{F}$

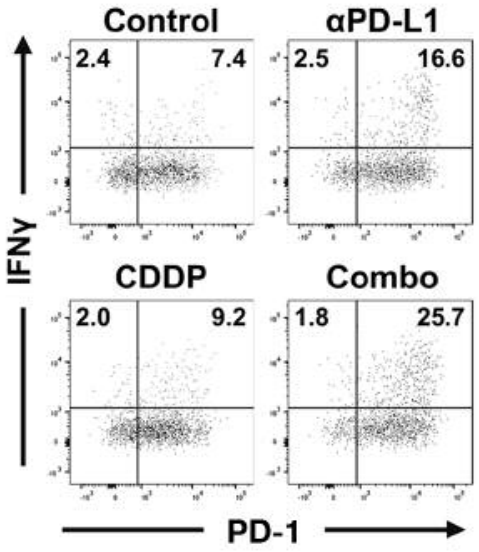

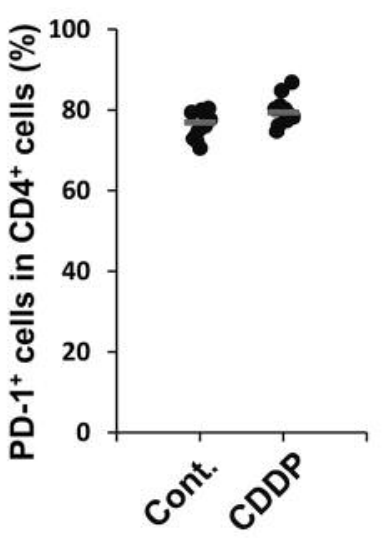

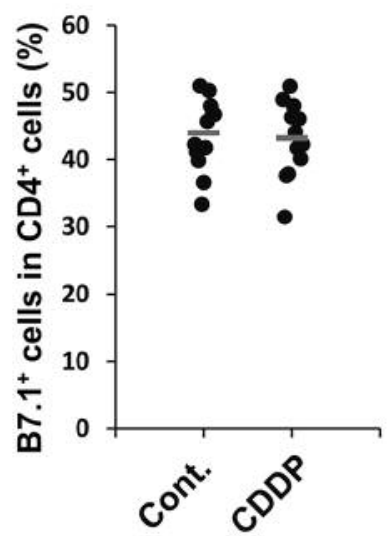

G

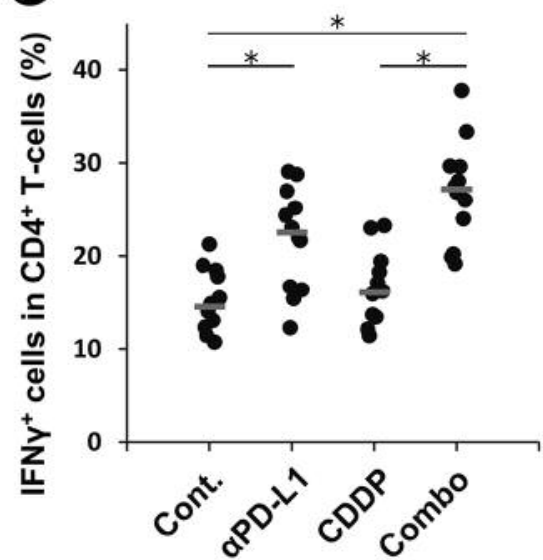

Figure 7. Anti-programed death-ligand 1 (PD-L1) treatment increased interferon-gamma (IFN $\gamma)$-producing CD4 ${ }^{+}$T-cells in tumor tissues. E.G7-OVAbearing mice were treated with $10 \mathrm{mg} / \mathrm{kg}$ anti-PD-L1 ( $\alpha P D-L 1)$ on day 1 and day 3, $1 \mathrm{mg} / \mathrm{kg}$ cisplatin $(C D D P)$ on day 1 , or a combination of both (combo). On day 7, tumor tissues were collected and used for flow cytometry. $\mathrm{CD} 3{ }^{+} \mathrm{CD} 4^{+}$cells $(\mathrm{A})$ and forkhead box $\mathrm{P} 3(\mathrm{FOXP} 3)^{+} \mathrm{CD} 4^{+}$cells $(\mathrm{B})$ were detected by flow cytometry and the numbers of these cells per mg of tumor tissue were calculated. Dots represent the value for each mouse and bars show the median of 12 mice per group. No significant difference was detected by the Wilcoxon test. The percentages of PD1 ${ }^{+}$and B7.1 ${ }^{+}$cells among $\mathrm{CD}^{+}{ }^{+}$-cells were determined by flow cytometry. $C$ : Representative flow cytometric profiles gated on $C D 4^{+} T$-cells. Quantitative analysis of PD-1+ $(D)$ and B7.1+ $(E)$ cells. Dots represent the value for each mouse and bars show the median of 12 mice per group. No significant difference was detected by the Wilcoxon test. The cells prepared from tumor tissues were stimulated ex vivo with anti-CD3 and anti-CD28, and IFN $\gamma$-producing cells were detected by flow cytometry. F: Representative flow cytometric profiles gated on $\mathrm{CD}^{+}{ }^{+}$-cells. G: Quantitative analysis of IFN $\gamma^{+}$cells. Dots represent the value for each mouse and bars show the median of 12 mice per group. *Significantly different at $p<0.05$, Wilcoxon test with Holm-Bonferroni method. 
the expression of PD-1 and B7.1 on $\mathrm{CD}^{+}$T-cells in tumor tissues, and found that most $\mathrm{B} 7.1^{+} \mathrm{CD} 4^{+}$T-cells co-expressed PD-1, which was similar to the results found with $\mathrm{CD}^{+} \mathrm{T}$-cells (Figures 3C and 7C). However, in contrast with $\mathrm{CD}^{+} \mathrm{T}$-cells, the expression of PD-1 and B7.1 on $\mathrm{CD}^{+}{ }^{+}$T-cells was not affected by cisplatin treatment (Figure 7D and E). Importantly, functional analysis showed that treatment with anti-PD-L1 alone and with combination therapy, but not treatment with cisplatin alone, profoundly increased IFN $\gamma$-producing $\mathrm{CD}^{+} \mathrm{T}$ cells in response to ex vivo stimulation compared with the control, and these increases were preferential in the PD- $1^{+}$ population (Figure $6 \mathrm{~F}$ and $\mathrm{G}$ ). These results suggest that $\mathrm{CD} 4^{+}$ T-cells are also activated by anti-PD-L1 plus cisplatin combination therapy and that induction of Th1 responses would contribute to the enhancement of $\mathrm{CD} 8^{+} \mathrm{T}$-cell activity in the tumor-bearing host.

\section{Discussion}

Here we demonstrated that cisplatin, which is used as a standard-of-care treatment in a broad range of cancer types, in combination with anti-PD-L1 resulted in a curative therapeutic effect in a syngeneic E.G7-OVA tumor model. We also found that combination therapy augmented the function of tumorinfiltrating $\mathrm{CD}^{+}$and $\mathrm{CD}^{+}$T-cells and resulted in a therapeutic effect. Remarkably, although cisplatin is primarily a chemotherapeutic drug, treatment with cisplatin alone activated $\mathrm{CD}^{+} \mathrm{T}$-cell responses against tumors, and the $\mathrm{CD}^{+}$ T-cells played a critical role in the antitumor effect. These observations were consistent with those of other reports in which cisplatin exhibited $\mathrm{CD}^{+}$T-cell-mediated therapeutic effect in other tumor-bearing mouse models (26, 27). Therefore, although the immune-suppressive effects of cisplatin are known to be directly toxic to circulating immune cells, our results indicate that $\mathrm{CD}^{+} \mathrm{T}$-cell immune responses play a crucial role in tumor eradication by cisplatin in this model.

Concomitant with cancer immunotherapy, anticancer druginduced ICD has been increasing in importance as a therapeutic strategy for the treatment of cancer because it elicits a variety of immune responses (18). As mentioned above, we found that depletion of $\mathrm{CD}^{+} \mathrm{T}$-cells abrogated the antitumor effects of cisplatin in the E.G-7-OVA-bearing mouse model. We also found increased expression of CXCL9 and CXCL10, which are known to be induced by ICD-mediated responses $(28,29)$. These results suggest that cisplatin-mediated ICD would contribute to activation of immune responses. Although there are reports showing increased antigen presentation and activation of dendritic cells after cisplatin treatment $(26,27)$, cisplatin is generally thought to be a poor inducer of ICD. The standard markers of ICD are the release of ATP and high mobility group box 1 and the translocation of calreticulin to the cell membrane after drug treatment in vitro (30). In the case of E.G7-OVA, cisplatin was reported to induce translocation of calreticulin to the cell membrane only in the presence of endoplasmic reticulum stress (18), suggesting that in some tumor microenvironments, cisplatin may cause ICD with additional stress. Indeed, IFN $\gamma$ treatment has been shown to cause endoplasmic reticulum stress in head and neck squamous cell carcinoma cell lines (31), and expression of calreticulin on cell membranes of human breast cancer cells increased after cisplatin plus IFN $\gamma$ treatment (32). Therefore, because anti-PD-L1 treatment activates immune responses including IFN $\gamma$ production at the tumor site, anti-PDL1 plus cisplatin combination therapy may lead to ideal conditions for cisplatin to induce ICD which may contribute to boosting the therapeutic effects.

In contrast with activation of the immune system through induction of ICD, reports have shown increased PD-L1 expression on tumor cells after treatment with chemotherapeutic agents, including cisplatin, which led to suppression of the function of CTLs $(20,21)$. This is another rationale for combination therapies with chemotherapy such as cisplatin with anti-PD-L1/PD-1. Furthermore, in addition to the chemotherapeutic modulation of tumor cells, we also found that expression of PD-1 and B7.1 was increased on tumor-infiltrating $\mathrm{CD} 8^{+} \mathrm{T}$-cells (but not $\mathrm{CD} 4^{+} \mathrm{T}$-cells) after cisplatin treatment. This would be a distinct line of evidence for proposing combination therapy with cisplatin and anti-PDL1, because anti-PD-L1 blocks both PD-L1-PD-1 and PDL1-B7.1 pathways. Further precise analysis is needed in order to reveal the mechanisms by which PD-1 and B7.1 are upregulated on $\mathrm{CD}^{+}$T-cells after cisplatin treatment and to reveal the contribution that these immune checkpointexpressing T-cells make to the therapeutic effect.

$\mathrm{CD}^{+}{ }^{+}$helper T-cells, especially IFN $\gamma$-producing Th1 cells, play an important role in generating and maintaining CTL cells during antitumor immune responses. A recent report shows that tumor tissues from patients with gastrointestinal cancer harbor neoantigen-specific Th1 cells, and adaptive transfer of the tumor-specific Th1 cells resulted in regression of the lesions, indicating that tumor-specific Th1 cells substantially augment antitumor immune responses in patients with cancer (23). However, few studies have investigated the impact of immune checkpoint inhibitors on $\mathrm{CD}^{+}$helper T-cells in antitumor immune responses. Although we found in the current study that anti-PD-L1 but not cisplatin administration elicited IFN $\gamma$-producing $\mathrm{Th} 1$ responses in tumor tissues (Figure $7 \mathrm{~F}$ and $\mathrm{G}$ ), the precise mechanisms underlying anti-PD-1/PD-L1-induced induction of Th1 and its role in antitumor activity need to be elucidated.

As immunotherapy begins to be used in patients with a wider range of cancer types, for further progression of cancer therapeutic strategies, it is essential to understand how standardof-care treatment may lead to maximal effects when used in combination with immunotherapy. Our results provide proof of principle that combination therapy with anti-PD-L1 and cisplatin offers robust antitumor effects in a mouse model 
through activation of tumor-specific $\mathrm{CD} 8^{+} \mathrm{T}$-cells. Although monotherapy with immune checkpoint inhibitors does not sufficiently benefit all patients with cancer, our findings suggest that anti-PD-L1 plus cisplatin combination therapy will likely result in higher clinical efficacy in a broader patient population.

\section{Conflicts of Interest}

All Authors are employees of Chugai Pharmaceutical Co., Ltd.

\section{Authors' Contributions}

D.W. designed, performed, and analyzed experiments, and wrote the manuscript. T.I., S.H., and M.S. contributed to therapeutic experiment design. M.S. and K.Y. organized this study and edited the manuscript.

\section{Acknowledgements}

The Authors thank Masako Miyazaki and Hiromi Sawamura at Chugai Pharmaceutical Co., Ltd. for their technical assistance with drug administration, and also thank Dr Kazushige Mori and Dr Kaori Fujimoto-Ouchi at Chugai Pharmaceutical Co., Ltd. for their helpful support and advice in this study.

\section{References}

1 Borghaei H, Paz-Ares L, Horn L, Spigel DR, Steins M, Ready NE, Chow LQ, Vokes EE, Felip E, Holgado E, Barlesi F, Kohlhaufl M, Arrieta O, Burgio MA, Fayette J, Lena H, Poddubskaya E, Gerber DE, Gettinger SN, Rudin CM, Rizvi N, Crino L, Blumenschein GR, Jr., Antonia SJ, Dorange C, Harbison CT, Graf Finckenstein F and Brahmer JR: Nivolumab versus docetaxel in advanced nonsquamous non-small-cell lung cancer. N Engl J Med 373(17): 1627-1639, 2015. PMID: 26412456. DOI:10.1056/NEJMoa1507643

2 Wolchok JD, Kluger H, Callahan MK, Postow MA, Rizvi NA, Lesokhin AM, Segal NH, Ariyan CE, Gordon RA, Reed K, Burke MM, Caldwell A, Kronenberg SA, Agunwamba BU, Zhang X, Lowy I, Inzunza HD, Feely W, Horak CE, Hong Q, Korman AJ, Wigginton JM, Gupta A and Sznol M: Nivolumab plus ipilimumab in advanced melanoma. N Engl J Med 369(2): 122133, 2013. PMID: 23724867. DOI:10.1056/NEJMoa1302369

3 Rittmeyer A, Barlesi F, Waterkamp D, Park K, Ciardiello F, von Pawel J, Gadgeel SM, Hida T, Kowalski DM, Dols MC, Cortinovis DL, Leach J, Polikoff J, Barrios C, Kabbinavar F, Frontera OA, De Marinis F, Turna H, Lee JS, Ballinger M, Kowanetz M, He P, Chen DS, Sandler A, Gandara DR and Group OAKS: Atezolizumab versus docetaxel in patients with previously treated non-small-cell lung cancer (OAK): A phase 3, open-label, multicentre randomised controlled trial. Lancet 389(10066): 255-265, 2017. PMID: 27979383. DOI: 10.1016/S0140-6736(16) 32517-X

4 Reck M, Rodriguez-Abreu D, Robinson AG, Hui R, Csoszi T, Fulop A, Gottfried M, Peled N, Tafreshi A, Cuffe S, O'Brien M, Rao S, Hotta K, Leiby MA, Lubiniecki GM, Shentu Y, Rangwala R, Brahmer JR and KEYNOTE-024 Investigators: Pembrolizumab versus chemotherapy for PD-L1-positive non-small-cell lung cancer. N Engl J Med 375(19): 1823-1833, 2016. PMID: 27718847. DOI: $10.1056 /$ NEJMoa1606774
5 Lebbe C, Weber JS, Maio M, Neyns B, Harmankaya K, Hamid O, O'Day SJ, Konto C, Cykowski L, McHenry MB and Wolchok JD: Survival follow-up and ipilimumab retreatment of patients with advanced melanoma who received ipilimumab in prior phase ii studies. Ann Oncol 25(11): 2277-2284, 2014. PMID: 25210016. DOI: $10.1093 / \mathrm{annonc} / \mathrm{mdu} 441$

6 Topalian SL, Sznol M, McDermott DF, Kluger HM, Carvajal RD, Sharfman WH, Brahmer JR, Lawrence DP, Atkins MB, Powderly JD, Leming PD, Lipson EJ, Puzanov I, Smith DC, Taube JM, Wigginton JM, Kollia GD, Gupta A, Pardoll DM, Sosman JA and Hodi FS: Survival, durable tumor remission, and long-term safety in patients with advanced melanoma receiving nivolumab. J Clin Oncol 32(10): 1020-1030, 2014. PMID: 24590637. DOI: 10.1200/jco.2013.53.0105

7 Zou W, Wolchok JD and Chen L: PPD-L1 (B7-H1) and PD-1 pathway blockade for cancer therapy: Mechanisms, response biomarkers, and combinations. Sci Transl Med 8(328): 328rv324, 2016. PMID: 26936508. DOI: 10.1126/scitranslmed.aad7118

8 Pardoll DM: The blockade of immune checkpoints in cancer immunotherapy. Nat Rev Cancer 12(4): 252-264, 2012. PMID: 22437870. DOI: $10.1038 / \mathrm{nrc} 3239$

9 Tumeh PC, Harview CL, Yearley JH, Shintaku IP, Taylor EJ, Robert L, Chmielowski B, Spasic M, Henry G, Ciobanu V, West AN, Carmona M, Kivork C, Seja E, Cherry G, Gutierrez AJ, Grogan TR, Mateus C, Tomasic G, Glaspy JA, Emerson RO, Robins H, Pierce RH, Elashoff DA, Robert C and Ribas A: PD1 blockade induces responses by inhibiting adaptive immune resistance. Nature 515(7528): 568-571, 2014. PMID: 25428505. DOI: $10.1038 /$ nature 13954

10 Rizvi NA, Hellmann MD, Snyder A, Kvistborg P, Makarov V, Havel JJ, Lee W, Yuan J, Wong P, Ho TS, Miller ML, Rekhtman N, Moreira AL, Ibrahim F, Bruggeman C, Gasmi B, Zappasodi R, Maeda Y, Sander C, Garon EB, Merghoub T, Wolchok JD, Schumacher TN and Chan TA: Cancer immunology. Mutational landscape determines sensitivity to PD-1 blockade in non-small cell lung cancer. Science 348(6230): 124-128, 2015. PMID: 25765070. DOI: $10.1126 /$ science.aaa1348

11 Schumacher TN and Schreiber RD: Neoantigens in cancer immunotherapy. Science 348(6230): 69-74, 2015. PMID: 25838375. DOI: $10.1126 /$ science.aaa4971

12 Chabanon RM, Pedrero M, Lefebvre C, Marabelle A, Soria JC and Postel-Vinay S: Mutational landscape and sensitivity to immune checkpoint blockers. Clin Cancer Res 22(17): 43094321, 2016. PMID: 27390348. DOI: 10.1158/1078-0432.ccr-160903

13 Woller N, Gurlevik E, Fleischmann-Mundt B, Schumacher A, Knocke S, Kloos AM, Saborowski M, Geffers R, Manns MP, Wirth TC, Kubicka S and Kuhnel F: Viral infection of tumors overcomes resistance to PD-1-immunotherapy by broadening neoantigenome-directed t-cell responses. Mol Ther 23(10): 16301640, 2015. PMID: 26112079. DOI: 10.1038/mt.2015.115

14 McArthur GA and Ribas A: Targeting oncogenic drivers and the immune system in melanoma. J Clin Oncol 31(4): 499-506, 2013. PMID: 23248252. DOI: 10.1200/jco.2012.45.5568

15 Vincent J, Mignot G, Chalmin F, Ladoire S, Bruchard M, Chevriaux A, Martin F, Apetoh L, Rebe C and Ghiringhelli F: 5fluorouracil selectively kills tumor-associated myeloid-derived suppressor cells resulting in enhanced t cell-dependent antitumor immunity. Cancer Res 70(8): 3052-3061, 2010. PMID: 20388795. DOI: $10.1158 / 0008-5472 . c a n-09-3690$ 
16 Ghiringhelli F, Menard C, Puig PE, Ladoire S, Roux S, Martin F, Solary E, Le Cesne A, Zitvogel L and Chauffert B: Metronomic cyclophosphamide regimen selectively depletes $\mathrm{CD} 4{ }^{+} \mathrm{CD} 25^{+}$ regulatory $\mathrm{T}$ cells and restores $\mathrm{t}$ and $\mathrm{nk}$ effector functions in end stage cancer patients. Cancer Immunol Immunother 56(5): 641648, 2007. PMID: 16960692. DOI: 10.1007/s00262-006-0225-8

17 de Biasi AR, Villena-Vargas J and Adusumilli PS: Cisplatininduced antitumor immunomodulation: A review of preclinical and clinical evidence. Clin Cancer Res 20(21): 5384-5391, 2014. PMID: 25204552. DOI: 10.1158/1078-0432.ccr-14-1298

18 Galluzzi L, Buque A, Kepp O, Zitvogel L and Kroemer G: Immunogenic cell death in cancer and infectious disease. Nat Rev Immunol 17(2): 97-111, 2017. PMID: 27748397. DOI: 10.1038/ nri.2016.107

19 Shalapour S, Font-Burgada J, Di Caro G, Zhong Z, SanchezLopez E, Dhar D, Willimsky G, Ammirante M, Strasner A, Hansel DE, Jamieson C, Kane CJ, Klatte T, Birner P, Kenner L and Karin M: Immunosuppressive plasma cells impede T-cell-dependent immunogenic chemotherapy. Nature 521(7550): 94-98, 2015. PMID: 25924065. DOI: 10.1038/nature14395

20 Peng J, Hamanishi J, Matsumura N, Abiko K, Murat K, Baba T, Yamaguchi K, Horikawa N, Hosoe Y, Murphy SK, Konishi I and Mandai M: Chemotherapy induces programmed cell death-ligand 1 overexpression via the nuclear factor-kappab to foster an immunosuppressive tumor microenvironment in ovarian cancer. Cancer Res 75(23): 5034-5045, 2015. PMID: 26573793. DOI: 10.1158/0008-5472.CAN-14-3098

21 Zhang P, Ma Y, Lv C, Huang M, Li M, Dong B, Liu X, An G, Zhang W, Zhang J, Zhang L, Zhang S and Yang Y: Upregulation of programmed cell death ligand 1 promotes resistance response in non-small-cell lung cancer patients treated with neo-adjuvant chemotherapy. Cancer Sci 107(11): 1563-1571, 2016. PMID: 27581532. DOI: $10.1111 /$ cas. 13072

22 Spranger S, Dai D, Horton B and Gajewski TF: Tumor-residing batf3 dendritic cells are required for effector t cell trafficking and adoptive t cell therapy. Cancer Cell 31(5): 711-723 e714, 2017. PMID: 28486109. DOI: 10.1016/j.ccell.2017.04.003

23 Tran E, Turcotte S, Gros A, Robbins PF, Lu YC, Dudley ME, Wunderlich JR, Somerville RP, Hogan K, Hinrichs CS, Parkhurst MR, Yang JC and Rosenberg SA: Cancer immunotherapy based on mutation-specific $\mathrm{CD} 4{ }^{+} \mathrm{T}$ cells in a patient with epithelial cancer. Science 344(6184): 641-645, 2014. PMID: 24812403. DOI: $10.1126 /$ science. 1251102

24 Pardoll DM and Topalian SL: The role of CD4+ $\mathrm{T}$ cell responses in antitumor immunity. Curr Opin Immunol 10(5): 588-594, 1998. PMID:9794842.

25 Takeshima T, Chamoto K, Wakita D, Ohkuri T, Togashi Y, Shirato $\mathrm{H}$, Kitamura $\mathrm{H}$ and Nishimura T: Local radiation therapy inhibits tumor growth through the generation of tumor-specific ctl: Its potentiation by combination with $\mathrm{TH} 1$ cell therapy. Cancer Res 70(7): 2697-2706, 2010. PMID: 20215523. DOI: 10.1158/00085472.can-09-2982

26 Jackaman C, Majewski D, Fox SA, Nowak AK and Nelson DJ: Chemotherapy broadens the range of tumor antigens seen by cytotoxic CD8(+) t cells in vivo. Cancer Immunol Immunother 61(12): 2343-2356, 2012. PMID: 22714286. DOI: 10.1007/ s00262-012-1307-4

27 Beyranvand Nejad E, van der Sluis TC, van Duikeren S, Yagita H, Janssen GM, van Veelen PA, Melief CJ, van der Burg SH and Arens R: Tumor eradication by cisplatin is sustained by CD80/86- mediated costimulation of $\mathrm{CD}^{+} \mathrm{T}$ cells. Cancer Res 76(20): 6017-6029, 2016. PMID: 27569212. DOI: 10.1158/00085472.CAN-16-0881

28 Sistigu A, Yamazaki T, Vacchelli E, Chaba K, Enot DP, Adam J, Vitale I, Goubar A, Baracco EE, Remedios C, Fend L, Hannani D, Aymeric L, Ma Y, Niso-Santano M, Kepp O, Schultze JL, Tuting T, Belardelli F, Bracci L, La Sorsa V, Ziccheddu G, Sestili P, Urbani F, Delorenzi M, Lacroix-Triki M, Quidville V, Conforti R, Spano JP, Pusztai L, Poirier-Colame V, Delaloge S, PenaultLlorca F, Ladoire S, Arnould L, Cyrta J, Dessoliers MC, Eggermont A, Bianchi ME, Pittet M, Engblom C, Pfirschke C, Preville X, Uze G, Schreiber RD, Chow MT, Smyth MJ, Proietti E, Andre F, Kroemer G and Zitvogel L: Cancer cell-autonomous contribution of type i interferon signaling to the efficacy of chemotherapy. Nat Med 20(11): 1301-1309, 2014. PMID: 25344738. DOI: $10.1038 / \mathrm{nm} .3708$

29 Hong M, Puaux AL, Huang C, Loumagne L, Tow C, Mackay C, Kato M, Prevost-Blondel A, Avril MF, Nardin A and Abastado JP: Chemotherapy induces intratumoral expression of chemokines in cutaneous melanoma, favoring T-cell infiltration and tumor control. Cancer Res 71(22): 6997-7009, 2011. PMID: 21948969. DOI: 10.1158/0008-5472.CAN-11-1466

30 Kepp O, Senovilla L, Vitale I, Vacchelli E, Adjemian S, Agostinis P, Apetoh L, Aranda F, Barnaba V, Bloy N, Bracci L, Breckpot K, Brough D, Buque A, Castro MG, Cirone M, Colombo MI, Cremer I, Demaria S, Dini L, Eliopoulos AG, Faggioni A, Formenti SC, Fucikova J, Gabriele L, Gaipl US, Galon J, Garg A, Ghiringhelli F, Giese NA, Guo ZS, Hemminki A, Herrmann M, Hodge JW, Holdenrieder S, Honeychurch J, Hu HM, Huang X, Illidge TM, Kono K, Korbelik M, Krysko DV, Loi S, Lowenstein PR, Lugli E, Ma Y, Madeo F, Manfredi AA, Martins I, Mavilio D, Menger L, Merendino N, Michaud M, Mignot G, Mossman KL, Multhoff G, Oehler R, Palombo F, Panaretakis T, Pol J, Proietti E, Ricci JE, Riganti C, Rovere-Querini P, Rubartelli A, Sistigu A, Smyth MJ, Sonnemann J, Spisek R, Stagg J, Sukkurwala AQ, Tartour E, Thorburn A, Thorne SH, Vandenabeele P, Velotti F, Workenhe ST, Yang H, Zong WX, Zitvogel L, Kroemer G and Galluzzi L: Consensus guidelines for the detection of immunogenic cell death. Oncoimmunology 3(9): e955691, 2014. PMID: 25941621. DOI: $10.4161 / 21624011.2014 .955691$

31 El Jamal SM, Taylor EB, Abd Elmageed ZY, Alamodi AA, Selimovic D, Alkhateeb A, Hannig M, Hassan SY, Santourlidis S, Friedlander PL, Haikel Y, Vijaykumar S, Kandil E and Hassan M: Interferon gamma-induced apoptosis of head and neck squamous cell carcinoma is connected to indoleamine-2,3-dioxygenase via mitochondrial and er stress-associated pathways. Cell Div 11: 11, 2016. PMID: 27486476. DOI: 10.1186/s13008-016-0023-4

32 Nolan E, Savas P, Policheni AN, Darcy PK, Vaillant F, Mintoff CP, Dushyanthen S, Mansour M, Pang JB, Fox SB, Kathleen Cuningham Foundation Consortium for Research into Familial Breast C, Perou CM, Visvader JE, Gray DHD, Loi S and Lindeman GJ: Combined immune checkpoint blockade as a therapeutic strategy for BRCA1-mutated breast cancer. Sci Transl Med 9(393): eaal4922, 2017. PMID: 28592566. DOI: 10.1126/ scitranslmed.aal4922

Received January 29, 2019

Revised February 26, 2019

Accepted February 27, 2019 